\title{
Methanococcus aeolicus sp. nov., a mesophilic, methanogenic archaeon from shallow and deep marine sediments
}

\author{
Melissa M. Kendall, ${ }^{1} \ddagger$ Yitai Liu, ${ }^{1}$ Magdalena Sieprawska-Lupa, ${ }^{3}$ \\ Karl O. Stetter, ${ }^{2}$ William B. Whitman ${ }^{3}$ and David R. Boone ${ }^{1} \dagger$ \\ ${ }^{1}$ Biology Department, Portland State University, PO Box 751, Portland, OR 97207-0751, USA \\ ${ }^{2}$ Universität Regensburg, Lehrstuhl für Mikrobiologie, Universitätstraße 31, 93343 Regensburg, \\ Germany \\ ${ }^{3}$ Department of Microbiology, University of Georgia, 541 Biological Sciences Building, Athens, \\ GA 30602-2605, USA
}

\begin{abstract}
Three strains of $\mathrm{CO}_{2}$-reducing methanogens were isolated from marine sediments. Strain PL-15/ $\mathrm{H}^{\mathrm{P}}$ was isolated from marine sediments of the Lipari Islands, near Sicily and the other two strains, Nankai-2 and Nankai- $3^{\top}$, were isolated from deep marine sediments of the Nankai Trough, about $50 \mathrm{~km}$ from the coast of Japan. Analysis of the cellular proteins and 16S rRNA gene sequences indicated that these three strains represented a single novel species that formed a deep branch of the mesophilic methanococci. Phylogenetic analysis indicated that the three strains were most closely related to Methanothermococcus okinawensis (95\% 16S rRNA gene sequence similarity). However, strains $\mathrm{PL}-15 / \mathrm{H}^{\mathrm{P}}$, Nankai-2 and Nankai-3 ${ }^{T}$ grew at temperatures that were more similar to those of recognized species within the genus Methanococcus. Strain Nankai- $3^{\top}$ grew fastest at $46{ }^{\circ} \mathrm{C}$. Results of physiological and biochemical tests allowed the genotypic and phenotypic differentiation of strains PL-15/ $\mathrm{H}^{\mathrm{P}}$, Nankai-2 and Nankai-3 ${ }^{\top}$ from closely related species. The name Methanococcus aeolicus sp. nov. is proposed, with strain Nankai- $3^{\top}$ $\left(=\mathrm{OCM} 812^{\top}=\mathrm{DSM} 17508^{\mathrm{T}}\right)$ as the type strain.
\end{abstract}

In 1984, novel restriction enzymes were found in a methanogenic archaeon, strain $\mathrm{PL}-15 / \mathrm{H}^{\mathrm{P}}$, which had been isolated from the Mediterranean Sea near Sicily (Schmid et al., 1984). At that time, it was suggested that this strain might represent a novel species, 'Methanococcus aeolicus'. Because the strain was not freely available due to patent restrictions, this species was not formally described. Nevertheless, the genetic and phylogenetic distinctiveness of strain PL-15/ $\mathrm{H}^{\mathrm{P}}$ from other Methanococcus species was confirmed by electrophoretic analysis of cellular proteins, DNA-DNA hybridization and 16S rRNA gene sequence analysis (Keswani et al., 1996). However, because of the

†Deceased 27 May 2005.

$\ddagger$ Present address: Department of Microbiology, University of Texas Southwestern Medical Center, 5323 Harry Hines Blvd, Dallas, TX 75390-9048, USA.

The GenBank/EMBL/DDBJ accession numbers for the 16S rRNA gene sequences of strains $\mathrm{PL}-15 / \mathrm{H}^{\mathrm{P}}$, Nankai-2 and Nankai-3 ${ }^{\top}$ are DQ136171, DQ195165 and DQ195164, respectively.

A figure showing the effects of temperature, $\mathrm{pH}$ and salinity on the growth of strain Nankai-3 ${ }^{\top}$ is available as supplementary material in IJSEM Online. absence of a type strain deposited in culture collections, the species 'Methanococcus aeolicus' has lacked standing in nomenclature (Whitman et al., 2001). Subsequently, sequences of $16 \mathrm{~S}$ rRNA genes very similar to that of strain $\mathrm{PL}-15 / \mathrm{H}^{\mathrm{P}}$ have been found in marine hydrothermal vent fluids (Huber et al., 2002), supporting the importance of this phylogenetic group in marine sediments.

We report here the isolation and description of two novel methanogenic strains (Nankai-2 and Nankai- $3^{\mathrm{T}}$ ) from deep marine sediments of the Nankai Trough off the coast of Japan, which are phylogenetically and phenotypically similar to strain $\mathrm{PL}-15 / \mathrm{H}^{\mathrm{P}}$. We also report the description and isolation of strain PL- $15 / \mathrm{H}^{\mathrm{P}}$, accomplished in the early 1980s. We propose that the three strains represent a novel species, Methanococcus aeolicus sp. nov., with strain Nankai$3^{\mathrm{T}}$ as the type strain and strains $\mathrm{PL}-15 / \mathrm{H}^{\mathrm{P}}$ and Nankai- 2 as reference strains.

Strain PL- $15 / \mathrm{H}^{\mathrm{P}}$ was isolated from shallow marine sediment collected from the Lipari Islands near Sicily. Strains Nankai2 and Nankai- $3^{\mathrm{T}}$ were enriched and isolated from sediment taken from the Nankai Trough near the coast of Japan in November 1997. Methanoculleus submarinus Nankai- $1^{\mathrm{T}}$ had 
been isolated previously from the same sample (Mikucki et al., 2003). At the sampling site, the water was $950 \mathrm{~m}$ deep, and the sample was obtained from a core at a depth of $247 \mathrm{~m}$ below the sediment surface, near the zone where methane hydrates occurred (Mikucki et al., 2003). The sample was placed in a canning jar, flushed with argon, sealed and maintained at $2-4{ }^{\circ} \mathrm{C}$ for 5 days until it was processed at the Idaho Environmental and Engineering Laboratory by Mark Delwiche (Mikucki et al., 2003). The core was then placed in an anaerobic chamber and pared, and $10 \mathrm{~g}$ from the interior of the core was added to $90 \mathrm{ml} \mathrm{MSH}$ medium in a serum bottle. The bottle was pressurized with $\mathrm{H}_{2}$ and incubated at room temperature. After 2 months, increases in $\mathrm{CH}_{4}$ in the headspace of the bottle ceased (Mikucki et al., 2003). This enrichment culture was then transported to Portland State University and inoculated into roll tubes in $\mathrm{MSH}$ enrichment medium under $\mathrm{H}_{2} / \mathrm{CO}_{2}$ (Mikucki et al., 2003). To distinguish colonies of methanogens from those of non-methanogens, unopened roll tubes were observed by epifluorescence microscopy (Zeiss O2 filter set). Two epifluorescent colonies were picked and named Nankai-2 and Nankai- $3^{\mathrm{T}}$. Each strain grew at $37^{\circ} \mathrm{C}$ and was further purified by colony picks from roll-tube cultures incubated at $37^{\circ} \mathrm{C}$.

Unless indicated otherwise, the culture medium used in this study was MSH medium (Boone et al., 1989; Ni \& Boone, 1991) at $\mathrm{pH} 7 \cdot 2$, with an overpressure of 1 atm $\mathrm{H}_{2}$. Incubations were at $37^{\circ} \mathrm{C}$ with shaking. $\mathrm{MSH}$ enrichment medium was the same as MSH medium except that the amounts of Trypticase peptones and yeast extract were reduced to $0 \cdot 25 \mathrm{~g} \mathrm{l}^{-1}$, mercaptoethane sulfonic acid was omitted and the sodium sulfide concentration was increased to $0.5 \mathrm{~g} \mathrm{l}^{-1}$. For experiments on the effect of salinity, $\mathrm{NaCl}$ was added to MSH medium to give various $\mathrm{Na}^{+}$concentrations. For preparation of media at different $\mathrm{pH}$ values, lower $\mathrm{pH}$ values were obtained by adjustment with $\mathrm{HCl}$. Higher $\mathrm{pH}$ values were obtained by using a mixture of $\mathrm{N}_{2}$ and $\mathrm{CO}_{2}$ for the gas phase (Chong et al., 2002). $\mathrm{pH}$ values above $7 \cdot 8$ were obtained by using a $100 \% \mathrm{CO}_{2}$ gas phase and adjusting the $\mathrm{pH}$ with $\mathrm{NaOH}$. The anaerobic Hungate technique with serum-tube modifications was used throughout (Hungate, 1969). Substrate tests were conducted by adding acetate $(40 \mathrm{mM})$, trimethylamine $(20 \mathrm{mM})$, methanol $(20 \mathrm{mM})$, ethanol $(1 \%, \mathrm{v} / \mathrm{v})$, 1-propanol (1\%), 2-propanol (1\%), 1-butanol (1\%) or 2 -butanol (1\%) to the medium. Growth was estimated from the accumulation of methane in the headspace gas, as measured by gas chromatography (Maestrojuán \& Boone, 1991), taking into account the methane produced during the growth of the inoculum (Powell, 1983). The specific growth rate was calculated by fitting the Gompertz equation (Zwietering et al., 1990) to these data. All growth experiments were performed in triplicate.

The 16S rRNA gene sequences were determined after extraction of DNA from cell pellets of pure cultures of strains PL-15/ $\mathrm{H}^{\mathrm{P}}$, Nankai-2 and Nankai- $3^{\mathrm{T}}$ by using QIAamp DNA
Mini kit procedures (Qiagen). The 16S rRNA genes were amplified by PCR, purified and sequenced as described previously (Singh et al., 2005). The sequences were aligned manually with related sequences obtained from the Ribosomal Database Project (Maidak et al., 2001). Regions where alignment was ambiguous were not used in the phylogenetic analysis. Phylogenetic relationships were determined with maximum-likelihood analysis using the HKY-85 model of evolution in PAUP* 4.0 (Swofford, 2002). A bootstrap analysis was performed using 1000 trial replications to provide confidence estimates for branch support. The sequence we obtained for strain PL- $15 / \mathrm{H}^{\mathrm{P}}$ was the same as the sequence already in GenBank (accession no. U39016), except that many of the unknown bases in the earlier sequence were successfully resolved. Whole proteins of strains PL-15/ $\mathrm{H}^{\mathrm{P}}$, Nankai-2 and Nankai- $3^{\mathrm{T}}$ were compared using SDS-PAGE of cellular proteins, as described previously (Franklin et al., 1988).

Colonies of strains PL- $15 / \mathrm{H}^{\mathrm{P}}$, Nankai-2 and Nankai- $3^{\mathrm{T}}$ were almost transparent and whitish, with smooth edges when observed by the naked eye or hand lens and $1 \mathrm{~mm}$ in diameter after 40 days of incubation at $37^{\circ} \mathrm{C}$. Cells of all three strains were motile irregular coccoids, $1 \cdot 5-2 \mu \mathrm{m}$ in diameter, and occurred singly. When viewed by epifluorescence microscopy with a Zeiss $\mathrm{O} 2$ filter set, cells were autofluorescent, as is typical of methanogens. Each of the three strains was susceptible to lysis with $0.01 \%$ SDS, suggesting the presence of a protein cell wall (Boone \& Whitman, 1988).

Each of the three strains grew with $\mathrm{H}_{2}(1 \mathrm{~atm})$ or formate $(80 \mathrm{mM})$ as electron donor for reduction of $\mathrm{CO}_{2}$. Cells did not form methane from acetate, trimethylamine or methanol, either alone or in combination with formate. In addition, in the mineral medium $\mathrm{McN}$ (Whitman et al., 1986), strain Nankai- $3^{\mathrm{T}}$ failed to form methane or grow in the presence of ethanol, 1-propanol or 2-propanol after 5 days of incubation. The concentrations of these potential catabolic substrates did not appear to be inhibitory as, when cultures were incubated with these concentrations plus 5 or $20 \mathrm{mM}$ formate, methane was formed in the amount expected from formate alone. In contrast, $1 \%$ 1-butanol and 2-butanol completely inhibited methanogenesis from formate.

Each strain grew autotrophically in MSH medium plus $\mathrm{H}_{2}$ when all organic compounds were omitted. Growth occurred even after four successive transfers with $2.5 \%$ (v/v) inoculum in mineral medium. In the $\mathrm{McN}$ mineral medium, growth of strain PL- $15 / \mathrm{H}^{\mathrm{P}}$ was stimulated by the addition of $11 \mu \mathrm{M}$ sodium selenite. Strain PL- $15 / \mathrm{H}^{\mathrm{P}}$ could also use either $\mathrm{S}^{0}$ or $\mathrm{H}_{2} \mathrm{~S}$ as the sole sulfur source and either $\mathrm{NH}_{3}$ or $\mathrm{N}_{2}$ as the sole nitrogen source. Amino acids were not used as nitrogen sources (Whitman et al., 1987).

Strain PL- $15 / \mathrm{H}^{\mathrm{P}}$ grew at $20-45^{\circ} \mathrm{C}$, but did not grow at $50^{\circ} \mathrm{C}$. Temperatures below $20^{\circ} \mathrm{C}$ were not tested. Strain Nankai-2 grew at $10-50^{\circ} \mathrm{C}$, with no growth at $55^{\circ} \mathrm{C}$ (temperatures 
Table 1. Comparison of physiological characteristics of isolates $P L-15 / H^{P}$, Nankai-2, Nankai-3 ${ }^{\top}$ and other recognized species of Methanococcus and Methanothermococcus

Species: 1, Methanococcus aeolicus $\mathrm{PL}-15 / \mathrm{H}^{\mathrm{P}} ; 2$, Methanococcus aeolicus Nankai-2; 3, Methanococcus aeolicus Nankai- $3^{\mathrm{T}}$; 4 , Methanococcus vannielii $\mathrm{SB}^{\mathrm{T}}$ (data from Stadtman \& Barker, 1951); 5, Methanococcus voltae $\mathrm{PS}^{\mathrm{T}}$ (Balch et al., 1979; Whitman et al., 1982); 6, Methanococcus maripaludis $\mathrm{JJ}^{\mathrm{T}}$ (Jones et al., 1983); 7, Methanothermococcus okinawensis $\mathrm{IH}^{\mathrm{T}}$ (Takai et al., 2002); 8, Methanothermococcus thermolithotrophicus $\mathrm{SN}-1^{\mathrm{T}}$ (Huber et al., 1982). ND, Not determined.

\begin{tabular}{|c|c|c|c|c|c|c|c|c|}
\hline \multirow[t]{2}{*}{ Characteristic } & \multicolumn{3}{|c|}{ Methanococcus aeolicus } & \multirow[t]{2}{*}{4} & \multirow[t]{2}{*}{5} & \multirow[t]{2}{*}{6} & \multirow[t]{2}{*}{7} & \multirow[t]{2}{*}{8} \\
\hline & 1 & 2 & 3 & & & & & \\
\hline Cell diameter $(\mu \mathrm{m})$ & $1 \cdot 5-2 \cdot 0$ & $1 \cdot 5-2 \cdot 0$ & $1 \cdot 5-2 \cdot 0$ & $1 \cdot 3$ & $1 \cdot 3-1 \cdot 7$ & $0 \cdot 9-1 \cdot 3$ & $1 \cdot 0-1 \cdot 5$ & $1 \cdot 5$ \\
\hline Autotrophic growth & + & + & + & + & - & + & + & \\
\hline Nitrogen source(s) & $\mathrm{NH}_{3}, \mathrm{~N}_{2}$ & $\mathrm{ND}$ & ND & $\mathrm{NH}_{3}$ & $\mathrm{NH}_{3}$ & $\mathrm{NH}_{3}, \mathrm{~N}_{2}$, alanine & $\mathrm{NH}_{3}$ & $\mathrm{~N}_{2}, \mathrm{NO}_{3}^{-}, \mathrm{NH}_{3}$ \\
\hline $\mathrm{Na}^{+}$range $(\mathrm{M})$ & $0 \cdot 05-0 \cdot 8$ & $0 \cdot 05-1 \cdot 0$ & $0 \cdot 05-1 \cdot 0$ & $0 \cdot 05-0 \cdot 8$ & $0 \cdot 08-0 \cdot 8$ & $0 \cdot 05-0 \cdot 8$ & $0 \cdot 08-1 \cdot 0$ & $0 \cdot 1-1 \cdot 6$ \\
\hline
\end{tabular}

${ }^{\star}$ Data from Whitman (2001).

below $10{ }^{\circ} \mathrm{C}$ were not tested). Strain Nankai- $3^{\mathrm{T}}$ grew at $20-55^{\circ} \mathrm{C}$, but not at 10 or $60^{\circ} \mathrm{C}$. The growth response of strain Nankai- $3^{\mathrm{T}}$ to temperature was fitted to the squareroot equation of Ratkowsky et al. (1982, 1983). Using this method, the theoretical optimum temperature for growth was determined to be $46.0{ }^{\circ} \mathrm{C}$, and the minimum and maximum temperatures were $7 \cdot 1$ and $54 \cdot 7^{\circ} \mathrm{C}$, respectively (Supplementary Fig. S1a in IJSEM Online). This temperature response was somewhat more thermophilic than that found in other methanococci. For instance, in $\mathrm{McN}$ medium, the temperature optima of Methanococcus maripaludis strains $\mathrm{JJ}^{\mathrm{T}}$ and $\mathrm{S} 2$ were $37^{\circ} \mathrm{C}$ and the maximum growth temperatures were $43^{\circ} \mathrm{C}$ (no growth at $45^{\circ} \mathrm{C}$ ) and $47^{\circ} \mathrm{C}$, respectively (W. B. Whitman, unpublished data; Jones et al., 1983). In contrast, the temperature optima and maxima for Methanothermococcus species are much more extreme, being greater than 60 and $70^{\circ} \mathrm{C}$, respectively (Table 1). Salinity and $\mathrm{pH}$ ranges for strains Nankai- $3^{\mathrm{T}}$, Nankai-2 and PL-15/ $\mathrm{H}^{\mathrm{P}}$ are given in Table 1 and are shown for strain Nankai-3 $3^{\mathrm{T}}$ (see Supplementary Fig. S1b, c in IJSEM Online).

The 16S rRNA gene sequences of each of the three strains were more similar to each other ( $>99 \%$ ) than to any other sequence in GenBank. Fig. 1 shows an evolutionary tree based on a maximum-likelihood-generated comparison of the $16 \mathrm{~S}$ rRNA gene sequences. As noted previously by Takai et al. (2002), Methanococcus aeolicus is more closely related using this method to the thermophile Methanothermococcus okinawensis ( $95 \%$ sequence similarity) than to the other mesophilic methanococci (91-93\% sequence similarity). In 2001, the genus Methanococcus was reorganized to include all mesophilic species, which at that time formed a monophyletic group of the Methanococcales (Whitman et al., 2001). The thermophile Methanococcus thermolithotrophicus was also transferred to a new genus, Methanothermococcus. The discovery of Methanothermococcus okinawensis suggested that this classification scheme might be too simplistic.

\footnotetext{
$63 \mid$ Methanococcus aeolicus PL-15/HP (DQ136171)

0.05 $\quad 100$ Methanococcus aeolicus Nankai-2 (DQ195165)

$\prod_{91}^{94}\left[\begin{array}{l}\text { Methanococcus aeolicus Nankai-3 }{ }^{\mathbf{T}} \text { (DQ195164) } \\ \text { Methanothermococcus okinawensis } \mathrm{IH}^{\top} \text { (AB057722) }\end{array}\right.$

Methanococcus voltae $\mathrm{PS}^{\top}$ (M59290)
}

http://ijs.sgmjournals.org

1527
Fig. 1. Maximum-likelihood phylogenetic tree of Methanococcus species and strains PL$15 / H^{P}$, Nankai-2 and Nankai-3 ${ }^{\top}$, based on $16 S$ rRNA gene sequences. Numbers at nodes are percentage bootstrap values based on 1000 iterations; only values $>50 \%$ are shown. Sequences of Thermocladium modestius strain IC-125 ${ }^{\top}$ (GenBank accession no. AB005296) and Acidianus infernus So $4 \mathrm{a}^{\top}$ (accession no. D85505) were used as outgroups (not shown). Bar, 0.05 substitutions per site. 


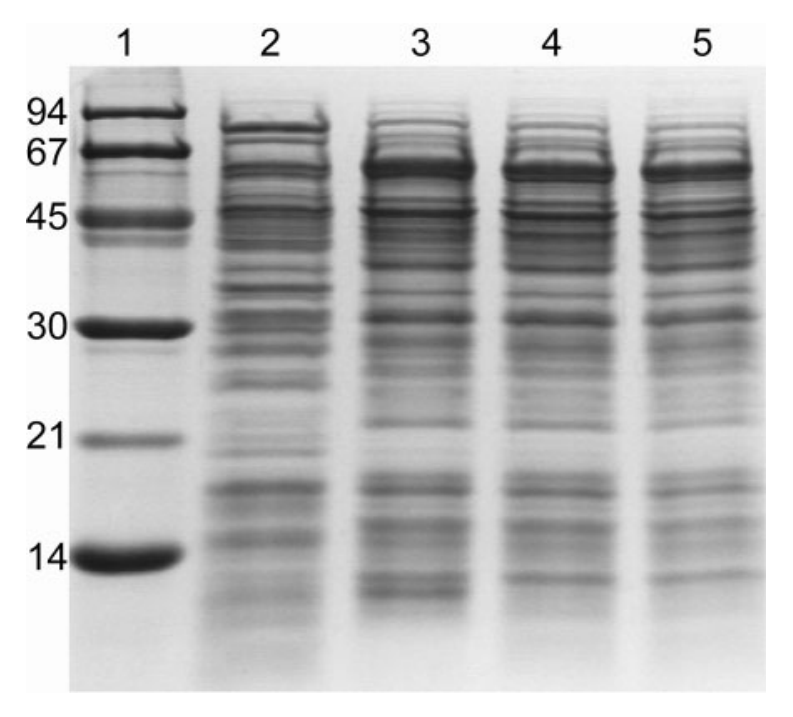

Fig. 2. SDS-PAGE of cellular proteins of strains $P L-15 / H^{P}$, Nankai-2 and Nankai-3 $3^{\top}$. Lanes: 1, molecular mass markers (in $\mathrm{kDa}$ ); 2, Methanococcus maripaludis strain $\mathrm{S} 2 ; 3$, strain $\mathrm{PL}-15 / \mathrm{H}^{\mathrm{P}} ; 4$, strain Nankai-2; 5 , strain Nankai-3 ${ }^{\top}$.

Because this thermophile forms a new clade with the mesophile Methanococcus aeolicus in rRNA gene trees, growth temperature may not prove to be a reliable discriminatory factor within this group. Since Methanothermococcus okinawensis and Methanococcus aeolicus both possess low sequence similarity to other Methanothermococcus species as well as to Methanococcus species, a new genus for these species may be warranted. This conclusion is supported by the elevated temperature optimum of Methanococcus aeolicus and the fact that the two species are present in submarine sediments. Nevertheless, in the absence of additional unifying characteristics, these criteria are judged insufficient in themselves to justify formation of a novel genus.

The overall similarity of the protein profiles of strains PL-15/ $\mathrm{H}^{\mathrm{P}}$, Nankai-2 and Nankai- $3^{\mathrm{T}}$ was within the range observed for members of the same species of other methanococci and was quite different from the protein profile of Methanococcus maripaludis (Fig. 2; Keswani et al., 1996). The protein profiles of strains Nankai- 2 and Nankai- $3^{\mathrm{T}}$ were very similar; however, several physiological differences existed between these strains (Table 1).

Based on their cellular protein profiles, 16S rRNA gene sequences and phenotypic properties, strains $\mathrm{PL}-15 / \mathrm{H}^{\mathrm{P}}$, Nankai-2 and Nankai- $3^{\mathrm{T}}$ are all closely related and belong in the same species. Nevertheless, these strains are physiologically distinct, as shown in Table 1 , and small differences are observed in their cellular protein profiles. DNA-DNA hybridization and cellular protein profiles also confirm that strain $\mathrm{PL}-15 / \mathrm{H}^{\mathrm{P}}$ is distinct from other described species of Methanococcus (Keswani et al., 1996). Thus, we propose that strains $\mathrm{PL}-15 / \mathrm{H}^{\mathrm{P}}$, Nankai-2 and Nankai- $3^{\mathrm{T}}$ represent a novel species, with the name Methanococcus aeolicus sp. nov.

\section{Description of Methanococcus aeolicus sp. nov.}

Methanococcus aeolicus (ae.o'li.cus. L. masc. adj. aeolicus Æolian, referring to the Lipari Islands near Sicily, the source of the first isolated strain).

Coccoid cells, $1 \cdot 5-2 \mu \mathrm{m}$ in diameter and occurring singly, motile and sensitive to lysis by detergent. Strictly anaerobic, growing autotrophically by reduction of $\mathrm{CO}_{2}$ to $\mathrm{CH}_{4}$, with $\mathrm{H}_{2}$ (or formate) as electron donor. Acetate, methanol, methylamines, ethanol, 1-propanol and 2-propanol are not catabolized. 1-Butanol and 2-butanol inhibit methane production. $\mathrm{N}_{2}$ or $\mathrm{NH}_{3}$ may serve as nitrogen source; $\mathrm{H}_{2} \mathrm{~S}$ or $S^{0}$ may serve as sulfur source. Selenium stimulates growth. Grows fastest at mesophilic temperatures or slightly above $\left(46^{\circ} \mathrm{C}\right)$, near neutral $\mathrm{pH}$ and at salinities of $0 \cdot 2-0 \cdot 4 \mathrm{M} \mathrm{Na}^{+}$. Maximum specific growth rate is approximately $0.5 \mathrm{~h}^{-1}$. The $\mathrm{G}+\mathrm{C}$ content of the DNA of strain $\mathrm{PL}-15 / \mathrm{H}^{\mathrm{P}}$ is $32 \mathrm{~mol} \%$ (by chromatographic analysis of bases). Habitat is marine sediments.

The type strain is strain Nankai- $3^{\mathrm{T}}\left(=\mathrm{OCM} 812^{\mathrm{T}}=\mathrm{DSM}\right.$ $\left.17508^{\mathrm{T}}\right)$; strains PL- $15 / \mathrm{H}^{\mathrm{P}}\left(=\mathrm{OCM} 836^{\mathrm{P}}=\right.$ DSM $\left.17251^{\mathrm{P}}\right)$ and Nankai-2 ( = OCM 811$)$ are reference strains.

\section{Acknowledgements}

We thank T. Uchida (Japanese Petroleum Exploration Company), Mark Delwiche and Fredrick S. Colwell (both Idaho National Environmental and Engineering Laboratory) for providing the core samples from the Nankai Trough. We also acknowledge J. P. Euzéby for help with the etymology of the species name. This work was supported by grants from the US Department of Energy's Subsurface Science program to the Subsurface Microbial Culture Collection (DOE prime contract DE-FG02-96ER62210 through purchase order G09965 from Florida State University), the National Science Foundation's LExEn program (prime contract OCE-0085607 via subcontract from University of California at Irvine, L00OCE0085607) and an IGERT Environmental Subsurface Biosphere fellowship to M. M. K.

\section{References}

Balch, W. E., Fox, G. E., Magrum, L. J., Woese, C. R. \& Wolfe, R. S. (1979). Methanogens: reevaluation of a unique biological group. Microbiol Rev 43, 260-296.

Boone, D. R. \& Whitman, W. B. (1988). Proposal of minimal standards for describing new taxa of methanogenic bacteria. Int J Syst Bacteriol 38, 212-219.

Boone, D. R., Johnson, R. L. \& Liu, Y. (1989). Diffusion of the interspecies electron carriers $\mathrm{H}_{2}$ and formate in methanogenic ecosystems and its implications in the measurement of $K_{m}$ for $\mathrm{H}_{2}$ or formate uptake. Appl Environ Microbiol 55, 1735-1741.

Chong, S. C., Liu, Y., Cummins, M., Valentine, D. L. \& Boone, D. R. (2002). Methanogenium marinum sp. nov., a $\mathrm{H}_{2}$-using methanogen from Skan Bay, Alaska, and kinetics of $\mathrm{H}_{2}$ utilization. Antonie van Leeuwenhoek 81, 263-270. 
Franklin, M. J., Wiebe, W. J. \& Whitman, W. B. (1988). Populations of methanogenic bacteria in a Georgia salt marsh. Appl Environ Microbiol 54, 1151-1157.

Huber, H., Thomm, M., König, H., Thies, G. \& Stetter, K. O. (1982). Methanococcus thermolithotrophicus, a novel thermophilic lithotrophic methanogen. Arch Microbiol 132, 47-50.

Huber, J. A., Butterfield, D. A. \& Baross, J. A. (2002). Temporal changes in archaeal diversity and chemistry in a mid-ocean ridge subseafloor habitat. Appl Environ Microbiol 68, 1585-1594.

Hungate, R. E. (1969). A roll-tube method for the cultivation of strict anaerobes. Methods Microbiol 3B, 117-132.

Jones, W. J., Paynter, M. J. B. \& Gupta, R. (1983). Characterization of Methanococcus maripaludis sp. nov., a new methanogen isolated from salt marsh sediment. Arch Microbiol 135, 91-97.

Keswani, J., Orkand, S., Premachandran, U., Mandelco, L., Franklin, M. J. \& Whitman, W. B. (1996). Phylogeny and taxonomy of mesophilic Methanococcus spp. and comparison of rRNA, DNA hybridization, and phenotypic methods. Int J Syst Bacteriol 46, 727-735.

Maestrojuán, G. M. \& Boone, D. R. (1991). Characterization of Methanosarcina barkeri $\mathrm{MS}^{\mathrm{T}}$ and 227, Methanosarcina mazei S-6 ${ }^{\mathrm{T}}$, and Methanosarcina vacuolata $\mathrm{Z}-761^{\mathrm{T}}$. Int $J$ Syst Bacteriol 41, 267-274.

Maidak, B. L., Cole, J. R., Lilburn, T. G. \& 7 other authors (2001). The RDP-II (Ribosomal Database Project). Nucleic Acids Res 29, 173-174.

Mikucki, J. A., Liu, Y., Delwiche, M., Colwell, F. S. \& Boone, D. R. (2003). Isolation of a methanogen from deep marine sediments that contain methane hydrates, and description of Methanoculleus submarinus sp. nov. Appl Environ Microbiol 69, 3311-3316.

Ni, S. \& Boone, D. R. (1991). Isolation and characterization of a dimethyl sulfide-degrading methanogen, Methanolobus siciliae HI350, from an oil well, characterization of $M$. siciliae $\mathrm{T} 4 / \mathrm{M}^{\mathrm{T}}$, and emendation of M. siciliae. Int J Syst Bacteriol 41, 410-416.

Powell, G. E. (1983). Interpreting gas kinetics of batch culture. Biotechnol Lett 5, 437-440.

Ratkowsky, D. A., Olley, J., McMeekin, T. A. \& Ball, A. (1982). Relationship between temperature and growth rate of bacterial cultures. J Bacteriol 149, 1-5.

Ratkowsky, D. A., Lowry, R. K., McMeekin, T. A., Stokes, A. N. \& Chandler, R. E. (1983). Model for bacterial culture growth rate throughout the entire biokinetic temperature range. J Bacteriol 154, 1222-1226.

Schmid, K., Thomm, M., Laminet, A., Laue, F. G., Kessler, C., Stetter, K. O. \& Schmitt, R. (1984). Three new restriction endonucleases MaeI, MaeII and MaeIII from Methanococcus aeolicus. Nucleic Acids Res 12, 2619-2628.

Singh, N., Kendall, M. M., Liu, Y. \& Boone, D. R. (2005). Isolation and characterization of methylotrophic methanogens from anoxic marine sediments in Skan Bay, Alaska: description of Methanococcoides alaskense sp. nov., and emended description of Methanosarcina baltica. Int J Syst Evol Microbiol 55, 2531-2538.

Stadtman, T. C. \& Barker, H. A. (1951). Studies on the methane fermentation. X. A new formate-decomposing bacterium, Methanococcus vannielii. J Bacteriol 62, 269-280.

Swofford, D. L. (2002). PAUP ${ }^{*}$ : Phylogenetic Analysis Using Parsimony ( ${ }^{\star}$ and other methods). Sunderland, MA: Sinauer Associates.

Takai, K., Inoue, A. \& Horikoshi, K. (2002). Methanothermococcus okinawensis sp. nov., a thermophilic, methane-producing archaeon isolated from a Western Pacific deep-sea hydrothermal vent system. Int J Syst Evol Microbiol 52, 1089-1095.

Whitman, W. B. (2001). Genus I Methanococcus Kluyver and van Niel 1936, 400, emend. Barker 1936, 430, ${ }^{\mathrm{AL}} \mathrm{Mah}$ and Kuhn 1984b, 264 (Nom. Cons., Opinion 62 of the Jud. Comm. 1986a, 491) emend. In Bergey's Manual of Systematic Bacteriology, 2nd edn, vol. 1, pp. 236-242. Edited by D. R. Boone, R. W. Castenholz \& G. M. Garrity. New York: Springer.

Whitman, W. B., Ankwanda, E. \& Wolfe, R. S. (1982). Nutrition and carbon metabolism of Methanococcus voltae. J Bacteriol 149, 852-863.

Whitman, W. B., Shieh, J., Sohn, S., Caras, D. S. \& Premachandran, U. (1986). Isolation and characterization of 22 mesophilic methanococci. Syst Appl Microbiol 7, 235-240.

Whitman, W. B., Sohn, S., Kuk, S. \& Xing, R. (1987). Role of amino acids and vitamins in nutrition of mesophilic Methanococcus spp. Appl Environ Microbiol 53, 2373-2378.

Whitman, W. B., Boone, D. R., Koga, Y. \& Keswani, J. (2001). Taxonomy of methanogenic Archaea. In Bergey's Manual of Systematic Bacteriology, 2nd edn, vol. 1, pp. 211-213. Edited by D. R. Boone, R. W. Castenholz \& G. M. Garrity. New York: Springer.

Zwietering, M. H., Jongenburger, I., Rombouts, F. M. \& van't Riet, K. (1990). Modeling of the bacterial growth curve. Appl Environ Microbiol 56, 1875-1881. 